\author{
Жадан Ірина Василівна \\ кандидат психологічних наук, старший науковий співробітник, \\ завідувач лабораторії психології політичної поведінки молоді \\ Інститут соціальної та політичної психології НАПН України, \\ м. Київ, Україна \\ ORCID ID 0000-0001-5274-574X \\ Iryna_zhadan@ukr.net
}

\title{
КОМУНІКАТИВНИЙ ПОТЕНЦІАЛ РОЗВИТКУ ГРОМАДЯНСЬКОЇ КОМПЕТЕНТНОСТІ СТУДЕНТСЬКОЇ МОЛОДІ
}

Проаналізовано результати дослідження комунікативних практик громадянської самоідентифікації молоді в ракурсі перспектив розвитку компетентної громадянської поведінки. Експліковано смисли комунікативних практик студентства, які гальмують, а почасти й унеможливлюють розвиток громадянської компетентності, та визначено обставини, сприятливі для трансформування цих смислів у бажані (можливі, ідеальні). З'ясовано, що становлення громадянської компетентності гальмується: а) невідрефлексованістю ціннісних смислів громадянської активності (чому це потрібно мені, спільноті, державі?); б) уявленнями молоді про сучасність і актуальність сенсів індивідуалізації на противагу ідентифікації; в) неартикульованістю цілей громадянської активності молоді (що саме я можу змінити у своєму житті i функціонуванні держави?), що гальмує конструювання прогностичних моделей громадянської активності та іï результатів, тож студентство не бачить реальних можливостей для самореалізації у власній державі; г) обмеженістю смислів, що репрезентують інструментальні аспекти громадянської самоідентифікації; д) екстернальністю молоді, яка артикулює прагнення змінювати і контролювати своє життя і водночас відповідальність за все покладає на владу, не переживаючи при цьому когнітивного дисонансу; е) практикуванням молоддю міфів стабільності і справедливості, зокрема і в електоральному виборі; є) схематичністю і дискретністю смислів відповідальності, взаємодії участі, добробуту, які артикулюються як метафори-шаблони, без аналізу детермінант, засобів і форм та наслідків. Визначено ресурси комунікації, які можуть бути задіяні для конструювання тих смислів громадянської активності, які зумовлюють компетентну громадянську поведінку. Змодельовано ситуації комунікації, які стимулюватимуть трансформування метафоричних компонентів комунікативних практик громадянської самоідентифікації молоді.

Ключові слова: громадянська компетентність; ідентифікація; смисли; практики; комунікація.

\section{COMMUNICATION POTENTIAL OF STUDENT YOUTH CIVIC COMPETENCE DEVELOPMENT}

\author{
Iryna V. Zhadan \\ Ph. D. in Psychology, Senior Researcher, \\ Head of the Laboratory of Psychology of Youth Political Behavior, \\ Institute for Social and Political Psychology, \\ National Academy of Educational Sciences of Ukraine, \\ Kyiv, Ukraine \\ ORCID ID 0000-0001-5274-574X \\ Iryna_zhadan@ukr.net
}

\begin{abstract}
It is analyzed the results of the communication practices of youth's civic selfidentification in the context of the development of competent civic behavior. It is explicated the meanings of youth's communication practices which hinder and often prevent civic competence development; it is also determined the circumstances which are favorable for the transformation of those meanings into desirable (possible, ideal) ones. It is proved that civic competence formation is hindered by a) value meanings of civic participation which are not reflected (what do I, the community, and the state need it for?); b) youth's ideas on the current developments and the actuality of the meanings of individualization as the opposed to identification; c) non-articulated goals of youth's civic participation (what exactly can I change in my own life and in the performance of the state?), which hinders the construction of the
\end{abstract}


prognostic models of civic participation and its results, so the students don't see opportunities for selfrealization in their own state; d) restricted character of meanings which represent instrumental aspects of civic self-identification; e) externality of youth which articulates the desire to change and control their lives, and, at the same time, to shift the responsibility onto authorities without experiencing any cognitive dissonance; f) youth's practicing of stability and justice myths, particularly in their electoral choice; g) schematic and discrete character of the meanings for responsibility, participatory interaction, and wellbeing, which are articulated as metaphor-pattern without analysis of the determinants, means, forms and consequences. It is determined the communication resources which can be involved in the construction of the meanings of civic participation which provide the competent civic behavior. It is modelled the communicative situations which stimulate the transforming of metaphorical components of youth's civic self-identification communication practices.

Key words: civic competence; identification; meanings; practices; communication.

Постановка проблеми. Дослідження комунікативних практик та особливостей їхнього впливу на громадянську і національну самоідентифікацію студентства дало змогу визначити семантичні лакуни та проблемні зони цих процесів. У пропонованій статті отримані результати буде представлено в ракурсі їх упровадження: ми спробуємо на основі співвіднесення ідеального (бажаного, можливого) i реального (фактичного, наявного) у самоідентифікуванні студентства визначити комунікативний потенціал (Калмыков, 2014) розвитку громадянської компетентності молоді.

Аналіз останніх досліджень і публікацій, виокремлення нерозв'язаних частин загальної проблеми. Згідно з логікою конструктивно-дискурсивного підходу, у річищі якого здійснювалося наше дослідження, комунікація розглядається як процес продукування і відтворення спільних смислів. Відповідно, йтиметься про потенціал трансформування смислів комунікативних практик для розвитку “якостей і кваліфікаційних характеристик” громадян, їхньої здатності і готовності “до примноження не лише особистих, приватних, а й спільних надбань, тобто орієнтації на суспільне благо; їхнього почуття солідарності”, “готовності до вчинків, дій зусиль”, щодо яких не передбачається матеріальної компенсації (Munkler, 1997, p. 155).

3 огляду на виокремлені Дж. Равеном чинники компетентної поведінки, а також специфіку громадянської компетентності (насамперед трансверсальності, спрямованості на вирішення проблем у різних сферах діяльності) до основних детермінант іi розвитку відносимо: готовність до громадянської активності, спрямованої на спільне благо, яка базується на аналізі ситуації i прогнозуванні наслідків своїх дій; прагнення змінювати і контролювати власне життя та ініціювати зміни в найближчому оточенні; готовність і здатність підтримувати тих, хто впроваджує нове і прагне підвищувати ефективність діяльності; адекватне сприйняття власної ролі і ролі інших у функціонуванні спільнот та суспільства в цілому; адекватність уявлень про лідерство, відповідальність, взаємодію, рівність, участь, добробут, демократію (Равен, 2002).

Мета статті - визначити комунікативні ресурси розвитку громадянської компетентності молоді на основі зіставлення особливостей комунікативних практик громадянської самоідентифікації студентства з ознаками компетентної поведінки.

Виклад основного матеріалу дослідження. Емпіричне дослідження особливостей комунікативних практик громадянської самоідетифікації студентської молоді проводилося за авторською методикою у форматі семантичного диференціала, додатково застосовувалася методика “Хто Я?” (М. Куна і Т. Макпартленда в модифікації Т. Румянцевої); метафоричні компоненти комунікативних практик визначалися за спеціально розробленим опитувальником. У дослідженні взяли участь студенти вишів з усіх регіонів України, загалом 483 особи.

На основі аналізу результатів емпіричного дослідження були експліковані ті смисли комунікативних практик громадянської самоідентифікації студентської молоді, які гальмують, а почасти й унеможливлюють розвиток громадянської компетентності, та визначено комунікативні ресурси трансформування цих смислів у бажані (можливі, ідеальні).

Одним із найбільш артикульованих індикаторів громадянськості, як у наукових джерелах, так i різного роду прикладних моделях, є громадянська активність. Згідно з даними нашого дослідження, у комунікативних практиках молоді смисли активності представлені найбільш вагомо й артикулюються переважно в контексті особистісного розвитку. Кожен другий опитаний студент вибудовує свою ідентичність з уявлення про громадянську активність як ознаку зрілості особистості 
(далі в тексті - “активісти). Але чи йдеться саме про ту активність, яка $є$ індикатором громадянської компетентності?

Наскрізною у всіх комунікативних практиках молоді є тема власного інтересу (вигоди) від громадянської ідентифікації.

Кожен четвертий з тих, хто заявляє про громадянську активність як ознаку зрілості особистості, ідентифікує себе як громадянина на номінальному рівні і переконаний, що індивідуалізація важливіша за ідентифікацію, а тому не готовий ні діяти заради спільного блага, ні ініціювати суспільні зміни.

Більш як 60\% “активістів” тяжіють до стабільності й обирають політичні сили, орієнтуючись на лідера, досвід управління державою та обіцянки торжества справедливості і порядку. За таких настановлень проблематичною є здатність молоді підтримувати тих, хто впроваджує нове.

Понад половину “активістів” відповідальність за все, що відбувається в державі, покладають виключно на владу, а переважна більшість (близько 80\%) уявляють свою громадянську активність як контроль влади. Цього вочевидь недостатньо для того, щоб можна було говорити про адекватне сприйняття власної ролі і ролі інших у функціонуванні спільнот і суспільства в цілому та адекватність уявлень про відповідальність, взаємодію, участь.

На етапі теоретичного аналізу ми припускали, що громадянська самоідентифікація корелює 3 рівнем суб'єктності особи. За результатами емпіричних досліджень це припущення підтвердилось, але лише частково: виявилось, що комунікативні практики, які репрезентують смисли громадянської суб'єктності, фігурують в усіх моделях самоідентифікації, однак суб'єктні інтенції молоді однозначно не зумовлюють рівень громадянської самоідентифікації. Це особливо виразно виявилось у дослідженні метафоричних компонентів комунікативних практик молоді: було встановлено, що смисли метафоричних конструктів комунікативних практик, які репрезентують суб'єктні настановлення, відповідають переважно четвертому рівню в усіх моделях самоідентифікаиї̈, при цьому почасти декларуються поряд з відверто патерналістськими очікуваннями молоді без жодних ознак когнітивного дисонансу. Ми можемо пояснити це тим, що посилена артикуляція “активізму” як громадянської чесноти призвела до того, що молодь просто засвоїла цю максиму і транслює їі, поряд 3 тезою про пріоритетність цінностей особи, навіть не намагаючись “вбудувати” їх у власну картину світу.

Ідентифікаційні характеристики більшості респондентів відповідають теперішньому часу, а частка таких, що пов'язані з перспективами, побажаннями, намірами, мріями тощо, становить лише 1,7\%, тобто молодь не конструює образ власної активності в майбутньому.

Лише чверть респондентів мають намір жити і працювати в Україні. Утім, те, що молодь не уявляє своє майбутнє у власній країні, зумовлюється, на нашу думку, панівним дискурсом, який транслюють сьогодні всі політичні сили, медіа, батьки і педагоги. Вочевидь молодь оперує відверто запозиченими конструктами (на кшталт “я не зможу реалізувати себе”, "не бачу поки що реальних можливостей себе реалізувати” і т. ін.), які декларуються як абсолютно істинні і такі, що не потребують верифікації, переконуючи всіх і самих себе в неможливості самореалізації у своїй країні.

Концептуалізація громадянської самоідентифікації молоді грунтується на метафорі "цінності держави для людей”, яка репрезентується метафоричними смислами “беззаперечної цінності”, “обміну”, “безпеки” та “знецінення держави”.

Найбільш продуктивною для конструювання національної і громадянської ідентичності виявилася метафора беззаперечної цінності держави. Серед респондентів, які вибудовують свою громадянську самоідентифікацію з цієї метафори, найбільше тих, хто оперує смислами рівня метафоррегуляторів практичної діяльності, які Д. Бікертон відносив до зони розвитку (Bickerton, 1969). Вони частіше за інших долучаються до громадянських ініціатив та орієнтовані на вирішення проблем, прагнуть змінювати життя на краще, розглядають активне громадянство як інструмент змін на краще власного життя і країни. Водночас респонденти цієї групи частіше почуваються цілком вільними людьми і не збираються обмежувати свою свободу заради інших (табл.), що не кореспондується 3 цінністю відповідальної свободи як ознаки компетентної громадянськості.

Таблиця

Рівні метафоричних смислів комунікативних практик у різних моделях громадянської та національної самоідентифікації студентської молоді 


\begin{tabular}{|l|c|c|c|c|}
\hline $\begin{array}{l}\text { Показники громадянської } \\
\text { самоідентифікації }\end{array}$ & Знецінення & Безпека & Обмін & $\begin{array}{c}\text { Беззаперечна } \\
\text { цінність }\end{array}$ \\
\hline $\begin{array}{l}\text { суб’єктнісь життєвої } \\
\text { позиції }\end{array}$ & 4 & 4 & 4 & 4 \\
\hline $\begin{array}{l}\text { прийняття громадянської } \\
\text { відповідальності }\end{array}$ & $3-4$ & 3 & 3 & 3 \\
\hline потреба у свободі & $3-4$ & 2 & 2 & 2 \\
\hline $\begin{array}{l}\text { залучення до } \\
\text { громадянської взаємодії }\end{array}$ & 3 & 4 & 4 & 4 \\
\hline часова оріснтація & 4 & 4 & 4 & 4 \\
\hline дистанційованість влади & 1 & 2 & 2 & 3 \\
\hline $\begin{array}{l}\text { інтегрованість } \\
\text { у проблеми спільноти }\end{array}$ & 1 & 3 & 3 & 4 \\
\hline сенс громадянства & 1 & 4 & 2 & 4 \\
\hline $\begin{array}{l}\text { форми прояву } \\
\text { громадянськості }\end{array}$ & 4 & 3 & 4 & 2 \\
\hline
\end{tabular}

Найменш продуктивною для конструювання громадянської ідентичності виявилася метафора знецінення держави - рівні метафоричних смислів комунікативних практик громадянської самоідентифікації респондентів, які обрали іï як базову, виявилися найнижчими за більшістю параметрів, а за параметрами дистанційованості влади, інтегрованості в проблеми спільноти та цілей (сенсу) громадянства відповідали рівню знакової репрезентації, чого взагалі не траплялось в інших кластерах. Водночас представники цієї групи частіше за інших, коли йдеться про потребу у свободі, практикують метафори вищих рівнів, артикулюють потребу у свободі самостійно приймати рішення i визначати своє життя та усвідомлюють, що їхня свобода закінчується там, де починається свобода інших.

Рівні метафоричних смислів комунікативних практики молоді, які вибудовують громадянську ідентичність з моделей безпеки та обміну, співмірні за всіма показниками, відмінності виявлені лише в метафорах активності (перші частіше практикують метафори на рівні конструювання смислів активності, а другі - на рівні інтерпретації). При цьому серед респондентів, які вибудовують ідентичність із метафори обміну, достовірно більше тих, хто практикує метафоричні смисли нижчих рівнів, коли йдеться про прийняття громадянської відповідальності, дистанційованості влади та інтегрованості в проблеми спільноти.

Метафоричні смисли, що репрезентують дистанційованість влади, у жодній з моделей самоідентифікації молоді не сягають вище рівня інтерпретації. Переважно на рівні інтерпретації смислів залишаються і метафоричні конструкти, які репрезентують потребу у свободі (виняток становить модель знецінення держави, яку практикує найменше молоді). Відтак можемо говорити про брак готовності до співробітництва на засадах довіри, а отже і компетентної громадянської поведінки.

Узагальнюючи викладене, можемо констатувати, що базові смисли громадянської самоідентифікації молоді не відповідають тим, які потрібні для розвитку громадянської компетентності, оскільки:

а) молодь не відрефлексовує ціннісні смисли громадянської активності (чому це потрібно мені, спільноті, державі?), а значить, навряд чи можна говорити про вмотивовану громадянську активність;

б) сенси індивідуалізації видаються респондентам більш сучасними і продуктивними, ніж сенси ідентифікації; ці процеси сприймаються як різноспрямовані, а сама громадянська ідентифікація розцінюється як обмеження індивідуальності;

в) цілі громадянської активності молоді (що саме я можу змінити у своєму житті i функціонуванні держави?) дуже звужені і загалом недостатньо артикульовані в комунікативних практиках. Обмежені уявлення про цілі гальмують і конструювання прогностичних моделей громадянської активності та іiі результатів; мабуть, саме тому студентство не бачить реальних можливостей для самореалізації у власній державі;

г) смисли, що репрезентують інструментальні аспекти громадянської самоідентифікації, не передбачають активність, орієнтовану на розвиток (ідентифікація розглядається переважно як можливість контролювати владу й отримати захист, підтримку тощо), а часом до того ж негативно забарвлені (молодь вбачає у громадянській активності загрози для цілісності держави, а активістів 
нерідко підозрює в намаганні вирішити свої особисті проблеми). Останнє, на нашу думку, зумовлено ще й тим, що медіа все частіше вдаються до акцентування негативних мотивів, прикладів, наслідків активності громадян; громадські активісти все частіше пишуть у соціальних мережах про емоційне вигоряння і виснаження, а громадські об'єднання обстоюють інтереси своїх членів, почасти ігноруючи інтереси решти громадян;

д) артикулюючи готовність і прагнення змінювати і контролювати своє життя, молодь виявляє екстернальність, коли йдеться про відповідальність за себе і свій добробут, при цьому не переживаючи когнітивного дисонансу, що свідчить про дискретність простору смислів громадянської самоідентифікації молоді;

е) попри декларації самої молоді та очікування спільноти щодо іiі відкритості до змін студентство прагне стабільності і практикує міфологію справедливості, у тому числі й в електоральному виборі, що не свідчить про готовність впроваджувати нове чи підтримувати тих, хто це робить;

є) смисли відповідальності, взаємодії, участі, добробуту в комунікативних практиках молоді схематичні і дискретні, артикулюються на рівні метафор-шаблонів, без усвідомлення детермінант, засобів і форм та наслідків.

Які ж ресурси комунікації можуть бути задіяні для конструювання тих смислів громадянської активності, які відповідають уявленням про громадянську компетентність?

Слід визнати, що освіта загалом задовільно забезпечує формування когнітивної складової громадянської компетентності молоді. Водночас формування таких елементів компетентності, як готовність до активності, спрямованої на спільне благо; прагнення змінювати і контролювати власне життя; готовність і здатність підтримувати тих, хто впроваджує нове; зрештою, адекватність громадянських уявлень і сприйняття власної ролі, неможливе без консенсусу спільноти щодо прийнятних форм, мотивацій і способів громадянської активності.

На наше переконання, артикуляція цих проблем на різних рівнях комунікативної взаємодії дасть змогу молоді позбутися дискретності, поверховості смислів громадянської самоідентифікації $\mathrm{i}$ сприятиме розвитку громадянської компетентності.

Задля подолання дискретності смислів громадянської самоідентифікації, розвитку здатності молоді до аналізу, рефлексії і прогнозування наслідків громадянської активності можемо запропонувати можливі варіанти дизайну комунікативних “інтервенцій”:

-артикуляція кола проблем (громад, соціальних груп і суспільства в цілому), які не можуть бути вирішені без участі громадян;

-артикуляція найближчих і віддалених цілей громадянської активності на кожному з рівнів;

-обговорення прийнятності тих чи тих форм громадянської активності, визначення обмежень;

-артикуляція обмежень, пов'язаних 3 реалізацією права особи на свободу (відповідальна свобода);

-обговорення очікувань щодо держави ( якщо в основі взаємодії - обмін, то що можуть гарантувати громадяни державі і що має гарантувати держава громадянам?; якщо цінність держави не визнається, то яких очікувань слід позбутися?);

-обговорення очікувань громадян щодо влади (зокрема акцентування причин непродуктивності таких конструктів, як “справедливість”, “піклування про людей” тощо; артикуляція смислів довіри і солідарності);

-рефлексія переживань, пов'язаних з успішним і неуспішним досвідом (своїм і чужим) громадянської активності;

-артикуляція теми соціальної відповідальності, зокрема у контексті проблем екології, корупції, електорального вибору тощо;

-конструювання прогностичних моделей розвитку актуальних ситуацій (очікування, ресурси, обмеження, ціна результату), у яких активність і якість вибору громадян $є$ вирішальними (вибори, референдуми, збори громад тощо).

Окрему увагу слід приділити трансформуванню практик самопроєктування майбутнього. Найбільш продуктивною формою такої комунікації є ділові ігри. Загальна модель гри, яка допоможе молоді побачити ситуацію з різних боків і переосмислити завчені практики, може бути такою: 
1) унаочнення образу майбутнього і способу його досягнення (Яким я бачу себе у 25 років? Що я маю для цього зробити? Чого я очікую від держави (батьків, влади)?);

2) конструювання прогностичних моделей досягнення бажаного у своїй i чужій країні з огляду на: емоційні чинники, ресурс соціального капіталу, індивідуальнопсихологічні особливості, адаптаційні ресурси тощо;

3) SWOT-аналіз перспектив самоздійснення, втрат і здобутків на цьому шляху та унаочнення їх у метафоричних конструктах.

У кожному з епізодів стратегія і технології визначаються під конкретне завдання - артикуляції, інтерпретації, коригування, конструювання чи реконструювання смислів комунікативних практик самоідентифікації. 3 огляду на особливості метафоричних компонентів комунікативних практик, які розставляють акценти, дають змогу визначити ціннісні орієнтири; привертають та утримують увагу, насичують комунікацію виразними образами, здатними надовго зберігатися в пам'яті (Гутнер, 2008), варто окрему увагу приділити зміні статусу наявних і конструюванню нових метафор.

\section{Висновки.}

1. Смислам комунікативних практик громадянської самоідентифікації молоді властиві: дискретність, суперечливість, схематичність, спрямованість на індивідуальну вигоду. Смисли відповідальної свободи, розвитку, довіри і співробітництва, які є основою компетентної громадянської поведінки, у практиках молоді практично не артикульовані.

2. Розвиток громадянської компетентності на основі такого рівня практик самоідентифікації молоді не видається можливим. Тому одним із нагальних завдань освіти, медіа, громадянського суспільства має бути створення комунікативного середовища $\mathrm{i}$ здійснення “інтервенцій”, які сприятимуть трансформуванню смислів комунікативних практик громадянської самоідентифікації молоді.

Перспективи подальших досліджень ми вбачаємо у визначенні соціально-психологічних чинників середовища, сприятливого для розвитку громадянської компетентності.

\section{Список використаних джерел}

Гутнер, Г. Б. (2008). Смысл как основание коммуникативных практик Эпистемология \& философия науки. Т. XVIII, 4, 44-52.

Калмыков, А. А. (2014). Понятие “коммуникативный потенциал” в системе категорий коммуникативных наук. Журналист. Социальные коммуникации, 2 (14), 13-22.

Равен, Дж. (2002). Компетентность в современном обществе: выявление, развитие и реализация. Пер. с англ. Москва: Когито-Центр.

Bickerton, D. (1969). Prolegomena to Linguistic. Theory of Metaphor. Foundations of Language, 5 (1), 34-52.

Münkler, H. (1997) Der kompetente Bürger. B A. Klein, R. Schmalz-Bruns (Eds.), Politishe Beteiligung und Burgerengagement in Deutschland Möglichkeiten und Grenzen (c. 153-172). Bonn: Bundeszentrale für politische Bildung.

\section{References}

Bickerton, D. (1969). Prolegomena to Linguistic. Theory of Metaphor. Foundations of Language, 5 (1), 34-52. (in English)

Gutner, G. B. (2008). Smysl kak osnovaniye kommunikativnykh praktik [Meaning as the basis of communicative practices]. Epistemologiya \& filosofiya nauki, B. XVIII, 4, 44-52. (in Russian)

Kalmykov, A. A. (2014). Ponyatiye "kommunikativnyy potentsial" v sisteme kategoriy kommunikativnykh nauk [The concept of "communicative potential" in the system of categories of communicative sciences]. Zhurnalist. Sotsialnyye kommunikatsii, 2 (14), 13-22. (in Russian)

Münkler, H. (1997) Der kompetente Bürger. In A. Klein, R. Schmalz-Bruns (Eds.), Politishe Beteiligung und Burgerengagement in Deutschland Möglichkeiten und Grenzen (pp. 153-172). Bonn: Bundeszentrale für politische Bildung. (in German)

Raven, J. (2002). Kompetentnost v sovremennom obshchestve: vyyavleniye, razvitiye i realizatsiya [Competence in modern society: identification. development and implementation]. Moscow: Kogito-Tsentr. (in Russian) 